\title{
Induced pluripotent stem cells in the study of neurological diseases
}

\author{
Mario A Saporta,2*, Marica Grskovic ${ }^{1}$ and John T Dimos ${ }^{1 *}$
}

\begin{abstract}
Five years after their initial derivation from mouse somatic cells, induced pluripotent stem (iPS) cells are an important tool for the study of neurological diseases. By offering an unlimited source of patientspecific disease-relevant neuronal and glial cells, iPS cell-based disease models hold enormous promise for identification of disease mechanisms, discovery of molecular targets and development of phenotypic screens for drug discovery. The present review focuses on the recent advancements in modeling neurological disorders, including the demonstration of diseasespecific phenotypes in iPS cell-derived neurons generated from patients with spinal muscular atrophy, familial dysautonomia, Rett syndrome, schizophrenia and Parkinson disease. The ability of this approach to detect treatment effects from known therapeutic compounds has also been demonstrated, providing proof of principle for the use of IPS cell-derived cells in drug discovery.
\end{abstract}

\section{Introduction}

Neurological disorders account for $6.3 \%$ of the global burden of disease [1,2] and are expected to rise in incidence as the world population ages. Nevertheless, there are few effective drug treatments, probably due to a lack of human disease models and poor understanding of fundamental disease mechanisms.

Most neurological disorders are caused by dysfunction and eventual loss of specific, highly specialized subpopulations of neuronal and/or glial cells. As human neurons and glia are not readily available, pathophysiological studies have been traditionally limited to genetically engineered animal models or cell lines less relevant to disease pathophysiology, such as skin fibroblasts or *Correspondence: mario.saporta@ipierian.com; john.dimos@ipierian.com
'iPierian, Inc., 951 Gateway Blvd, South San Francisco, CA 94080, USA Full list of author information is available at the end of the article immortalized cell lines. While these surrogate models provide some insight into disease mechanisms, their genotype and phenotype differ considerably from those of disease-affected cells in vivo. This is particularly true for diseases where gene dosage seems to play an important role, such as in superoxide dismutase 1 (SOD1)associated familial amyotrophic lateral sclerosis (ALS) [3] and Charcot-Marie-Tooth disease type $1 \mathrm{~A}$, caused by PMP22 duplication $[4,5]$. To study these conditions, multiple copies of the mutant gene are inserted into animal models, artificially creating a phenotype that resembles the human disease but not necessarily recapitulating the biological mechanisms behind it.

Another example of a human disease that does not readily translate into animal models or traditionally used cell lines is spinal muscular atrophy (SMA), caused by deletions of the SMN1 gene [6]. In humans, the disease phenotype is modulated by the expression levels of $S M N 2$, which is absent in mice and other species commonly used as disease models $[7,8]$. In addition, even though SMN1 is ubiquitously expressed in all cells, motor neurons are primarily affected in SMA patients. Disease models should therefore reflect a specific pathophysiological context and cellular networks that exist in the disease-relevant cells.

The recent development of induced pluripotent stem (iPS) cell technology has provided a new paradigm for the generation and study of human disease-specific neuronal and glial cells relevant for investigating neurological disorders (Figure 1). Because this technology makes physiologically relevant, pathological cells available in limitless amounts, it will probably prove to be a more translational approach to study nervous system function and disease and to screen potentially therapeutic compounds more reliably. Here, we review the recent developments in the use of iPS cells to model neurological diseases and discuss the major challenges in moving the field forward.

\section{Induced pluripotent stem cells: generation and differentiation to neurologic disease-relevant cell lineages}

Embryonic-like iPS cells capable of differentiating into a variety of cells in the body can be derived from somatic 


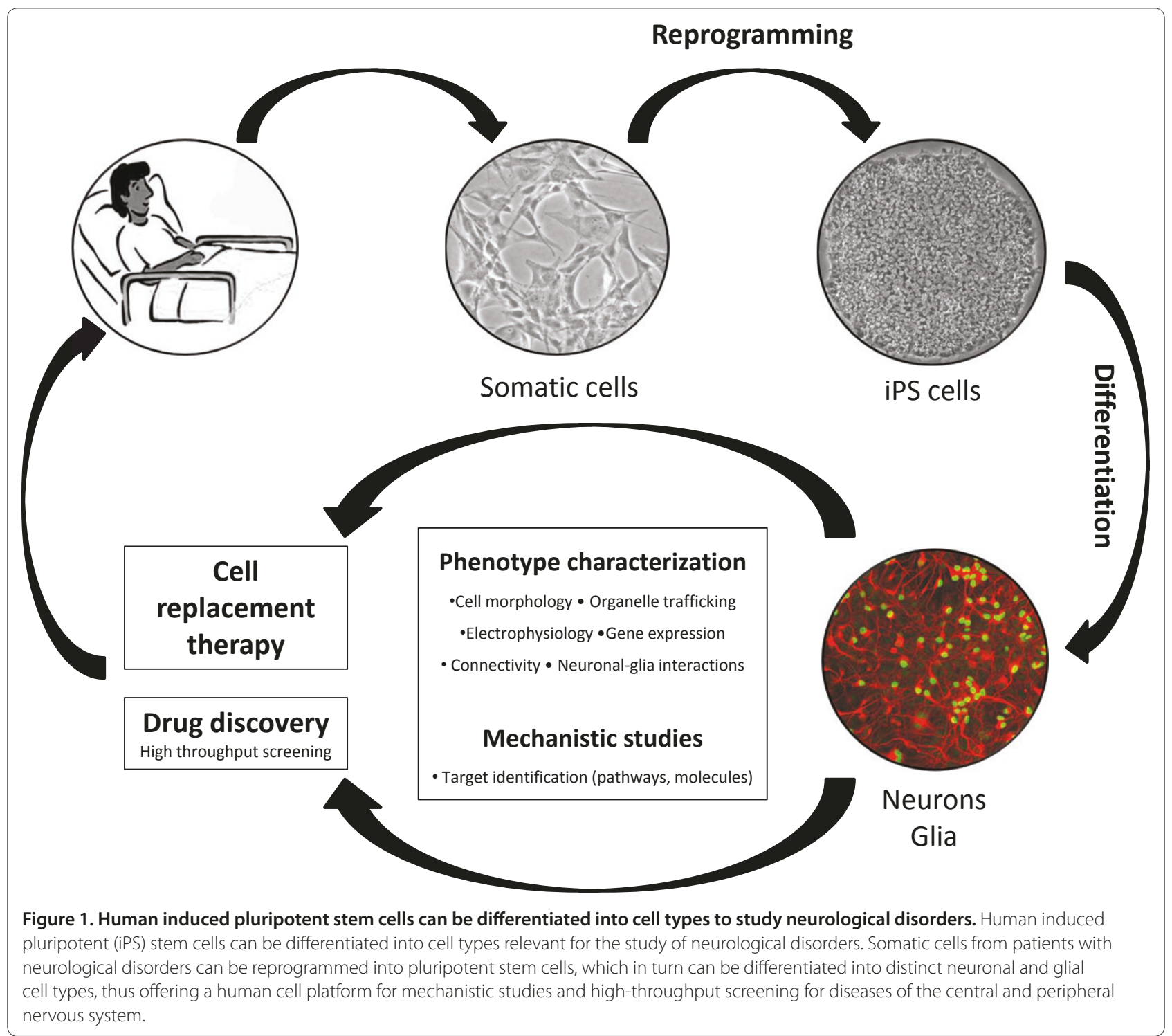

cells by the forced expression of defined factors [9-11]. Distinct factors, and strategies to induce their expression, have been employed for the generation of iPS cells from a number of human tissues using an array of approaches with varying degrees of efficiency [12]. To date, however, most patient iPS cell lines have been derived by retroviral transduction of dermal fibroblasts due to their accessibility and relatively high efficiency of reprogramming.

iPS cells can be coaxed into specific cell types by manipulation of the culture environment. Growth factors, small molecules and extracellular matrix proteins can be applied in a sequential manner to emulate the normal development of the cell lineage of interest. Using this approach, investigators have been able to differentiate human pluripotent cells into lineages necessary for modeling neurological diseases, including cholinergic
$[13,14]$, glutamatergic [15] and dopaminergic neurons $[16,17]$, astrocytes [13], oligodendrocytes [18] and Schwann cells $[19,20]$.

Spinal cord cholinergic motor neuron differentiation is one of the better studied among the aforementioned cell types and follows the same steps described during normal embryonic development [21]. The first step in differentiating iPS cells into neurons is inhibition of pathways such as those of transforming growth factor beta and bone morphogenetic protein [22]. iPS cells differentiate to neuroepithelia usually within a few days of compound treatment and assume a neural tube-like rosette morphology. This primitive neuroepithelium can be patterned to ventral spinal progenitors by treatment with retinoic acid and sonic hedgehog or one of its signaling agonists. Retinoic acid is the main signal for 
neurons to assume a caudal (spinal cord) profile, while sonic hedgehog determines a ventral (motor) identity. Further differentiation to mature spinal motor neurons can then be accomplished by addition of specific factors, such as brain-derived neurotrophic factor and glial cellderived neurotrophic factor, both of which promote axonal elongation [23]. This process usually takes around 3 to 6 weeks depending on the specific protocol, and can be monitored using a set of markers including PAX6 (neuroepithelia), OLIG2 (motor neuron progenitors), ISLET1/2 and HB9 (motor neurons), and acetylcholine transferase and synapsin (mature motor neurons), among others. Alternative approaches including the generation of embryoid bodies as an intermediate step have also been described [24]. Consistent with what is seen in normal development, glia cell differentiation only occurs after a prolonged time in culture, usually between 6 and 8 weeks.

\section{Modeling neurological diseases using iPS cells}

Identification of a disease-relevant phenotypic difference between cells derived from patients and from healthy individuals is one of the most challenging aspects of using iPS cells for disease modeling. This is particularly relevant for diseases where causative cellular pathophysiology is not clear, such as familial ALS or Alzheimer disease. Even though iPS cells have been derived from patients with a number of neurological diseases (summarized in the next sections and in Table 1), initial work has focused on modeling neurodevelopmental disorders - in particular, those with known genetic causes. Modeling genetically complex, late-onset diseases is probably more challenging, and may require exposing the cells to biological, chemical or environmental stressors to reveal pathological phenotypes. The examples discussed below demonstrate the value of iPS cell-based models for identification of disease mechanisms, discovery of molecular targets and development of phenotypic screens for drug discovery.

\section{Monogenic early-onset disorders Spinal muscular atrophy}

SMA (OMIM: 253300) is an autosomal recessive disease that affects one in every 6,000 to 10,000 live births, making it the most common neurogenetic disorder of infancy. SMA is caused by a decrease in levels of survival of motor neuron (SMN) protein due to deletions of the SMN1 gene. Even though SMN protein is ubiquitously expressed, its deficiency leads to a loss of motor neurons of the spinal cord ventral horns and consequent denervation of axial and limb muscles, represented clinically by muscle atrophy and weakness, dysphagia and respiratory failure in severe cases [25]. The clinical phenotype of SMA is modulated by the expression level of SMN2, a paralog almost identical to $S M N 1$. SMN2 generates low levels of the SMN protein that are not sufficient to prevent loss of motor neurons.

Past studies have largely relied on animal models or unaffected cell types such as patients' fibroblasts, providing limited insight into the disease mechanism and yielding ineffective drug treatments. In the first proof-ofprinciple study using iPS cells to model a disease, Ebert and colleagues generated iPS cells from a SMA patient and used them to derive motor neurons [14]. Interestingly, the authors found comparable size and number of motor neurons at 4 weeks of differentiation between the SMA and control cultures. By week 6, however, the SMA motor neurons were selectively reduced in number and size when compared with the control cells - suggesting that SMA motor neurons developed normally, but were more susceptible to degeneration. The authors identified a reduction in SMN aggregates (also termed gems) in SMA motor neurons, consistent with the reduced levels of SMN in these cells. The administration of valproic acid and tobramycin led to the increase of gems in SMA iPS cells. While this study did not show whether these compounds can elevate SMN levels or rescue the loss of patient-derived motor neurons, it provided an important validation for the utility of iPS-derived patient cells to model disease.

\section{Familial dysautonomia}

Familial dysautonomia (FD) is one of the hereditary sensory and autonomic neuropathies (type III, or RileyDay syndrome; OMIM: 223900). FD is an autosomal recessive disorder almost exclusive to individuals of Eastern European Jewish origin, affecting one in every 3,600 live births in this population. Clinically, it is characterized by feeding difficulty, alacrimia, orthostatic hypotension without compensatory tachycardia, and decreased pain and temperature perception. FD is usually fatal, with only one-half of the patients reaching adulthood, even with the best standard of care [26].

FD is caused by mutations in the IKBKAP gene [27] that lead to reduced transcriptional elongation of several target genes, some of which are required for cell motility [28]. In a recent study, Lee and colleagues generated iPS cell lines from three patients with FD and demonstrated several disease-relevant features specific to the patients' cell lines, including misregulated inhibitor of kappa light polypeptide gene enhancer in B cells, kinase complexassociated protein (IKBKAP) expression, defective neuronal differentiation and a decrease in FD neural crest precursor migration [29]. By comparing gene expression profiles of healthy and patient-derived neural crest precursors, genes involved in peripheral neurogenesis and neuronal differentiation were found to be differentially expressed in FD cells, providing insight into the molecular mechanism(s) of the disease. 
Table 1. Neurological and psychiatric diseases where iPS cells have been derived from affected individuals

\begin{tabular}{|c|c|c|c|c|}
\hline Disease & Reference & Molecular defect & $\begin{array}{l}\text { Phenotype of iPS-derived } \\
\text { cells }\end{array}$ & $\begin{array}{l}\text { Therapeutic response } \\
\text { (compound) }\end{array}$ \\
\hline Down syndrome & Park and colleagues [48] & Trisomy 21 & ND & ND \\
\hline \multirow[t]{2}{*}{$\begin{array}{l}\text { Lesch-Nyhan syndrome } \\
\text { (carrier state) }\end{array}$} & Park and colleagues [48] & $\begin{array}{l}\text { Heterozygous point mutations } \\
\text { in HPRTI gene }\end{array}$ & ND & ND \\
\hline & Khan and colleagues [55] & & & \\
\hline \multirow[t]{2}{*}{ Huntington disease } & Park and colleagues [48] & $\begin{array}{l}\text { Trinucleotide expansion in } \\
\text { HUNTINGTIN }\end{array}$ & ND & ND \\
\hline & Zhang and colleagues [50] & & $\begin{array}{l}\text { Enhanced caspase } 3 / 7 \text { activity } \\
\text { after growth factor withdrawal }\end{array}$ & ND \\
\hline \multirow{2}{*}{$\begin{array}{l}\text { Duchenne and Becker } \\
\text { muscular dystrophy }\end{array}$} & Park and colleagues [48] & Mutations in DYSTROPHIN & ND & ND \\
\hline & Kazuki and colleagues [49] & & & \\
\hline \multirow{2}{*}{$\begin{array}{l}\text { Familial amyotrophic } \\
\text { lateral sclerosis }\end{array}$} & Dimos and colleagues [13] & Mutations in SOD1 gene & ND & ND \\
\hline & Boulting and colleagues [34] & & & \\
\hline Spinal muscular atrophy & Ebert and colleagues [14] & Mutations in SMN1 gene & $\begin{array}{l}\text { Reduced size and number of } \\
\text { motor neurons, reduced SMN } \\
\text { protein in iPS cells }\end{array}$ & $\begin{array}{l}\text { Increased SMN gem number } \\
\text { in SMA iPS cells (valproic acid, } \\
\text { tobramycin) }\end{array}$ \\
\hline Familial dysautonomia & Lee and colleagues [29] & $\begin{array}{l}\text { Partial skipping of exon } 20 \text { of } \\
\text { IKBKAP, reduced IKAP protein }\end{array}$ & $\begin{array}{l}\text { Decreased expression of genes } \\
\text { involved in neurogenesis and } \\
\text { neuronal differentiation; defect in } \\
\text { neural crest migration }\end{array}$ & $\begin{array}{l}\text { Increase in the percentage of } \\
\text { differentiating neurons and in } \\
\text { the expression of peripheral } \\
\text { neuron markers (kinetin) }\end{array}$ \\
\hline Fragile X syndrome & Urbach and colleagues [56] & $\begin{array}{l}\text { Trinucleotide (CGG) } \\
\text { expansion, silencing of FMR1 }\end{array}$ & ND & ND \\
\hline \multirow[t]{2}{*}{$\begin{array}{l}\text { Angelman syndrome and } \\
\text { Prader-Willi syndrome }\end{array}$} & $\begin{array}{l}\text { Chamberlain and colleagues } \\
\text { [51] }\end{array}$ & $\begin{array}{l}\text { Chromosome } 15 q \text { deletion } \\
\text { (imprinting disorders) }\end{array}$ & ND & ND \\
\hline & Yang and colleagues [52] & & & \\
\hline \multirow[t]{6}{*}{ Parkinson disease } & Park and colleagues [48] & Unknown (sporadic) & ND & ND \\
\hline & Soldner and colleagues [16] & & & \\
\hline & $\begin{array}{l}\text { Swistowski and colleagues } \\
{[17]}\end{array}$ & & & \\
\hline & Hargus and colleagues [37] & & & \\
\hline & Nguyen and colleagues [38] & Mutations in LRRK2 & $\begin{array}{l}\text { Increased expression of stress- } \\
\text { response genes, increased } \\
\text { a-SYNUCLEIN levels and } \\
\text { oversensitivity to stress agents by } \\
\text { dopaminergic neurons }\end{array}$ & ND \\
\hline & Seibler and colleagues [42] & Mutations in PINK1 & $\begin{array}{l}\text { Impaired recruitment of Parkin } \\
\text { to mitochondria, increased } \\
\text { mitochondrial copy number, } \\
\text { upregulation of PGC-1a in } \\
\text { dopaminergic neurons }\end{array}$ & $\begin{array}{l}\text { Phenotype corrected by } \\
\text { expression of wildtype PINK1 }\end{array}$ \\
\hline \multirow[t]{3}{*}{ Rett syndrome } & Hotta and colleagues [57] & Mutation in MECP2 & $\begin{array}{l}\text { Decreased synapse number, } \\
\text { reduced spines, increased LINE1 } \\
\text { retrotransposon mobility }\end{array}$ & $\begin{array}{l}\text { Increase in glutamatergic } \\
\text { synapse number (IGF1); } \\
\text { increase in MeCP2 protein } \\
\text { levels and glutamatergic } \\
\text { synapse numbers (gentamicin) }\end{array}$ \\
\hline & $\begin{array}{l}\text { Marchetto and colleagues } \\
\text { [15] }\end{array}$ & & & \\
\hline & Muotri and colleagues [33] & & & \\
\hline Schizophrenia & Brennand and colleagues [47] & Unknown & $\begin{array}{l}\text { Reduced neurite density, } \\
\text { neuronal connectivity and } \\
\text { glutamate receptor expression; } \\
\text { altered gene expression of } \\
\text { components of the cyclic AMP } \\
\text { and WNT signaling pathways }\end{array}$ & $\begin{array}{l}\text { Increase in neuronal } \\
\text { connectivity and glutamate } \\
\text { receptor expression (loxapine) }\end{array}$ \\
\hline
\end{tabular}


Using iPS cell-derived neural crest cells as a drug screening platform, a partial rescue of the disease phenotype was achieved after administration of kinetin, a plant hormone previously shown to reduce levels of the mutant $I K B K A P$ splice form in FD-derived lymphoblast cell lines. Kinetin treatment of patient's cells significantly reduced the mutant IKBKAP splice form and increased the number of differentiating neurons; however, the level of increased IKBKAP did not lead to rescue of cell motility. Even though the identified compound only partially rescued the disease phenotype in this cellular model of FD, this study demonstrates the value of patient cellbased disease models for drug discovery using phenotypic screens, as well as for identifying novel molecular targets and disease mechanisms.

\section{Rett syndrome}

Rett syndrome (OMIM: 312750) is an X-linked autism spectrum disorder characterized by stagnation of developmental skills starting between 6 and 18 months of age, followed by developmental regression, hypotonia, seizures and autistic behavior. Affecting one in 10,000 to 20,000 females [30], it is caused by mutations in methyl CpG binding protein 2 (MeCP2), a protein involved in epigenetic and transcriptional regulation of a number of genes [31,32].

In a recent study, Marchetto and colleagues developed iPS cell lines from four female Rett patients, differentiated them into neurons and compared them with neurons derived from healthy individuals [15]. While no differences were observed in neurogenesis, mature Rett neurons were smaller with fewer dendritic spines and less glutaminergic excitatory synapses. Of note, this phenotype could be modulated by overexpression or knockdown of MeCP2 in neurons derived from control iPS cells, suggesting that $\mathrm{MeCP} 2$ is a rate-limiting factor in determining the glutaminergic synapse number in human neurons. Neurons derived from Rett iPS cells also demonstrated reduced frequency of calcium oscillations and spontaneous postsynaptic currents, suggesting a deficiency in neuronal network connectivity. Similarly to the FD study, the authors identified compounds that partially rescued the disease phenotype in patientderived cells. The same group has recently used iPS cells from Rett patients to investigate the role of MeCP2 in modulating long interspersed nuclear elements in neurons, providing yet another example of examining disease mechanisms in patient iPS cell-based models [33].

\section{Late-onset disorders}

Amyotrophic lateral sclerosis

ALS (or Lou-Gehrig's disease) is the most common motor neuron disease, with a prevalence of one to two per 100,000 worldwide. ALS is characterized by progressive loss of upper (cortical) and lower (spinal cord) motor neurons, with consequent spasticity, hyperreflexia and progressive weakness and muscle atrophy. It is a fatal disease with a mean overall survival between 3 and 4 years after presentation. Around $10 \%$ of cases have a genetic etiology, and animal models have been created based on genes identified in families with ALS. Unfortunately, no significant drug development has successfully translated from these studies into clinical practice.

In the first work to demonstrate that patient-specific iPS cells could be differentiated into motor neurons, Dimos and colleagues developed iPS cell lines from two patients with familial ALS caused by a SOD1 point mutation [13]. Of note, the patients were over 80 years old at the time of the study, demonstrating that iPS cells could be successfully generated even from mature skin fibroblasts of the elderly and differentiated into spinal motor neurons. Recently, Boulting and colleagues established a test set of 16 iPS cell lines from five healthy controls and two patients with SOD1 familial ALS, and demonstrated that all lines showed comparable efficiency in the generation of electrically active motor neurons [34]. The study found line-to-line phenotypic differences between distinct iPS cell lines; however, pair-wise comparisons did not reach statistical significance and concordance between lines differentiated in two independent laboratories was high, suggesting that the iPS cell platform is reproducible enough to allow for detection of consistent disease-specific phenotypes. Although an ALS disease phenotype in patient-derived iPS cells has yet to be demonstrated, iPS cell methodology enables us to create motor neurons from familial and sporadic ALS patients, and to identify common and diverse cellular disease phenotypes in different patients.

\section{Parkinson disease}

Parkinson disease (PD) is the second most common neurodegenerative disorder, affecting more than 6 million people worldwide [35]. It is characterized by selective loss of dopaminergic neurons in the substancia nigra pars compacta of the midbrain. PD is clinically defined by resting tremor, reduced spontaneous movements (bradikynesia), rigidity and postural instability. A group of nonmotor PD-related symptoms has been increasingly recognized [36], suggesting that other neuronal cell types may also be affected. Although PD is a treatable condition, neurodegeneration progresses despite symptomatic control, worsening symptoms and eventually reducing therapeutic efficacy. Dopaminergic neurons, the main cell population affected by $\mathrm{PD}$, have been differentiated from patient-derived iPS cells [16,17,37,38]. These neurons were successfully transplanted into rat brains, integrated to the neuronal circuitry, survived in 
significant numbers 12 weeks after transplantation and improved clinical phenotype as defined by a reduction of amphetamine rotational asymmetry [17,37], closely replicating previous experiments using human embryonic stem cell-derived dopaminergic neurons [39-41].

In a recent study, iPS cells were generated from a patient with a homozygous point mutation in the leucinerich repeat kinase-2 (LRRK2) gene, the most common cause of familial PD [38]. Dopaminergic neurons derived from these iPS cells demonstrated increased expression of stress-response genes, including $H S P B 1, N O X 1$ and $M A O B$, increased $\alpha$-SYNUCLEIN levels and oversensitivity to stress agents, such as peroxide and 6-hydroxydopamine. Seibler and colleagues recently derived iPS cells from patients with familial PD caused by mutations in the PTEN-induced putative kinase (PINK1) gene [42]. PINK1 is an outer mitochondrial membrane protein believed to regulate the translocation of PARKIN, another protein associated with familial PD, into damaged mitochondria. Patient iPS cell-derived dopaminergic neurons exhibited mitochondrial dysfunction that was alleviated by introduction of wildtype PINK1. Taken together, these data suggest that key features of PD pathophysiology could be recapitulated using the iPS cell approach. Potential disease mechanisms identified in dopaminergic neurons derived from iPS cells of familial PD patients could be further studied in cells derived from patients with sporadic forms of PD to help establish common downstream pathways amenable to therapeutic intervention.

\section{Neuropsychiatric disorders \\ Schizophrenia}

Schizophrenia is a devastating neuropsychiatric disease characterized by long duration of symptoms, delusions, lack of motivation, reduction in spontaneous speech and social withdrawal, and few affective symptoms [43]. Disease onset is usually in adolescence and early adulthood, which causes significant human and financial burden to patients, family and society as a whole [44]. The pathophysiology of schizophrenia is complex, including environmental as well as strong genetic components [45]. As with other neuropsychiatric conditions, generation of reliable animal models is limited and problematic [46]. A recent study demonstrated disease-specific phenotypes in iPS cell-derived neurons from four patients with schizophrenia, including reduced neurite density, neuronal connectivity and glutamate receptor expression, and altered gene expression of components of the cyclic AMP and WNT signaling pathways [47]. Of note, both neuronal connectivity and gene expression abnormalities were improved after a 3-week treatment with the antipsychotic loxapine.

\section{Other neurological diseases}

iPS cells have also been generated from patients with Duchenne and Becker muscular dystrophy $[48,49]$, Huntington disease [48,50], and the genomic imprinting disorders Angelman syndrome and Prader-Willi syndrome [51,52]. Although the resultant iPS cell lines carried the basic genetic abnormality for each disorder, no specific phenotype was described under standard culture conditions. However, several findings from these studies are noteworthy. Striatal neurons derived from Huntington disease iPS cells demonstrated enhanced caspase 3/7 activity after growth factor withdrawal [50]. iPS cells derived from patients with Angelman syndrome and Prader-Willi syndrome - neurodevelopmental disorders caused by lack of expression of genes contained in a specific region of chromosome 15 , and defined by the parental origin of the affected genetic material (imprinting) - maintained the appropriate DNA methylation imprint following reprogramming [51,52], validating the use of the iPS cell model in the investigation of imprinting diseases.

Recently, Kazuki and colleagues corrected the genetic abnormality in fibroblasts from a patient with Duchenne muscular dystrophy, due to a deletion of exons 4 to 43 of the human dystrophin gene, using a human artificial chromosome with a complete genomic dystrophin sequence [49]. At 2.4 megabases, DYSTROPHIN is the longest known gene, making gene replacement therapy particularly challenging, especially for patients with long deletions. The authors successfully derived iPS cells from the corrected fibroblasts, demonstrating the potential for combining gene therapy and iPS cell technology to generate patient-specific rescued cell lines for eventual use in cell replacement therapy.

\section{Challenges and limitations}

Despite the rapid progress in applying iPS cell technology to disease modeling, this promising platform is still in its infancy. Several issues remain to be tackled before iPS cells can be used as reliable models of acquired, multifactorial disorders and, eventually, as treatment strategies in regenerative medicine.

One immediate challenge is in using iPS cells to produce relevant differentiated and functional cell types. Current differentiation protocols attempt to mimic embryonic specification and patterning; for example, using signaling molecules to dial in the desired rostral/caudal and dorsal/ventral location. This approach, however, generally results in a heterogeneous cell population. While these mixed populations could be considered co-cultures in which, particularly, neurons are more amenable to long-term maturation and survival, they also present a possible challenge to phenotype identification. 
Simple biochemical and gene expression analyses cannot be performed across cultures without careful normalization for cell types and their proportions present, which may limit the study of conditions exclusively or preferentially affecting one cell type. However, approaching the differentiated culture similarly to a primary explant culture, such as dorsal root ganglia cultures where multiple cell types coexist, may be a useful strategy. In this approach, the heterogeneity of differentiated cultures is turned into an advantage where the cell type of interest can be studied within a broader milieu; for example, motor neurons with spinal cord interneurons and glial cells.

The use of cell type-specific reporter genes allows for identification and characterization of the target cell while preserving functionally meaningful interactions between neuronal and non-neuronal cells. Recently, new techniques to introduce reporter genes into cells have become available, including bacterial artificial chromosomes with fluorescent reporters [53] and zinc finger nucleases [54]. Zinc finger nuclease technology allows for the efficient and rapid production of knockin reporter cell lines, wherein sequences encoding fluorescent reporter proteins can be put under the control of any endogenous regulatory region. Such a labeling approach can in principle allow for any cell type to be identified or isolated, and the insertion of multiple fluorescent reporters in the same line would potentially allow for cell differentiation, maturation and function to be monitored in real time.

Another approach to study the cell type of interest in a complex culture would be to isolate the desired cell type at the end of differentiation using techniques such as fluorescence-activated cell sorting or magnetic bead separation. While combinatorial cell surface markers are well validated for the hematopoietic system, however, identifying surface markers specific for the target cell can be challenging, as is the case for spinal cord motor neurons. Which of the aforementioned strategies for analyzing heterogeneous cultures differentiated from iPS cells will prove to be the more adequate to characterize particular disease-relevant phenotypes is a matter for further study.

It remains unclear whether the iPS cell platform will be able to replicate the more complex, multifactorial pathophysiology of late-onset neurodegenerative disorders. It is possible that in these conditions a disease-relevant phenotype would only appear after a long quiescent period, hindering the use of iPS cells in the study of lateonset diseases. Diverse chemical, genetic or environmental stressors could be applied in such instances, however, in order to mature or age cells if necessary to reveal a phenotype. Additionally, some pathophysiology may require at least a partial recapitulation of central nervous system architecture. For example, possible defects in axonal transport in projection neurons might only be recapitulated in vitro when neurons are allowed to extend axons of significant length and complexity.

Another related issue, inherent to cell culture platforms, is the inability of the iPS cell model to replicate disease mechanism at the tissue or system levels including, for example, protein deposition or inflammation. On the other hand, the possibility to study a more isolated system may allow investigators to detect the initial steps of a disease process, otherwise superimposed to other subsequent responses. For example, while the iPS platform will probably not be able to replicate the complex anatomical and functional interactions between the distinct cell types affected by PD, the recent report of mitochondrial dysfunction in iPS cell-derived dopaminergic neurons from a specific familial form of PD demonstrates how this system can detect discrete cellular dysfunction that could otherwise be masked by end-stage changes in pathological specimens [42].

In spite of the challenges for harnessing its true potential, iPS cell technology is likely to prove advantageous for building novel human disease models. Differentiation protocols must be further improved while novel culture conditions needed to support iPS cell-derived cells and investigate their phenotypes are developed.

\section{Conclusions}

The development of iPS cell technology is opening a new avenue for the study of human, disease-specific, neuronal and glial cells that promises to revolutionize the neuroscience field. Since the publication of Takahashi and Yamanaka's seminal paper 5 years ago [9], iPS cell lines from more than a dozen distinct neurodevelopmental and neurodegenerative diseases have been established and specific disease phenotypes are starting to emerge. Future studies will probably focus on validating these disease phenotypes in platforms that will allow for the screening of therapeutic compounds and the discovery of biologic mechanisms underlying neurological diseases.

The widespread availability of human disease-specific cells will allow investigators the unprecedented opportunity to conduct mechanistic studies and determine causation in a human model system, rather than just correlation. This will allow in vitro phenotypes to be linked to disease pathology, enabling a better understanding of therapeutic manipulations that might lead to a disease-modifying effect.

Developing and validating new techniques to reprogram somatic cells into iPS cells without viral integration and to correct genetic abnormalities ex vivo are the next step in the effort to apply iPS cell technology in regenerative medicine, and are currently an active area of research. One can envision a near future where iPS cells will be used as a screening tool for personalized medicine and as a reservoir for cell replacement therapy. 
This article is part of a review series on Induced pluripotent stem cells. Other articles in the series can be found online at http://stemcellres.com/series/ipsc

\section{Abbreviations}

ALS, amyotrophic lateral sclerosis; FD, familial dysautonomia; IKBKAP, inhibitor of kappa light polypeptide gene enhancer in B cells, kinase complexassociated protein; iPS, induced pluripotent stem; LRRK2, leucine-rich repeat kinase 2; MECP2, methyl CpG binding protein 2; PD, Parkinson disease; PINK1, PTEN-induced putative kinase 1; SMA, spinal muscular atrophy; SMN, survival of motor neuron; SOD1, superoxide dismutase 1.

\section{Competing interests}

JTD and MG are employees of iPierian, Inc. MAS declares that he has no competing interests.

\section{Authors' contributions}

The present review was written and edited by MAS, MG and JTD.

\section{Acknowledgements}

The authors would like to thank members of their laboratories, Berta Strulovici, Irene Griswold-Prenner and Mike Shy for helpful discussions on this manuscript. MAS is a fellow of the Inherited Neuropathies Consortium - Rare Diseases Clinical Research Network - National Institutes of Health.

\section{Author details}

'iPierian, Inc., 951 Gateway Blvd, South San Francisco, CA 94080, USA.

2Department of Neurology, Wayne State University School of Medicine, $421 \mathrm{E}$

Canfield, Room 3209, Detroit, Ml 48201, USA.

Published: 21 September 2011

\section{References}

1. World Health Organization: Neurological Disorders: Public Health Challenge Geneva: World Health Organization; 2006.

2. World Health Organization: Global Burden of Disease and Risk Factors. 2004 Update. Geneva: World Health Organization; 2008

3. Nagai M, Aoki M, Miyoshi I, Kato M, Pasinelli P, Kasai N, Brown RH, Jr, Itoyama Y: Rats expressing human cytosolic copper-zinc superoxide dismutase transgenes with amyotrophic lateral sclerosis: associated mutations develop motor neuron disease. J Neurosci 2001, 21:9246-9254.

4. Niemann S, Sereda MW, Rossner M, Stewart H, Suter U, Meinck HM, Griffiths IR, Nave KA: The 'CMT rat': peripheral neuropathy and dysmyelination caused by transgenic overexpression of PMP22. Ann N Y Acad Sci 1999, 883:254-261

5. Robaglia-Schlupp A, Pizant J, Norreel JC, Passage E, Sabéran-Djoneidi D, Ansaldi JL, Vinay L, Figarella-Branger D, Lévy N, Clarac F, Cau P, Pellissier JF, Fontés M: PMP22 overexpression causes dysmyelination in mice. Brain 2002, 125:2213-2221.

6. Lefebvre S, Burglen L, Reboullet S, Clermont O, Burlet P, Viollet L, Benichou B, Cruaud C, Millasseau P, Zeviani M, Le Paslier D, Frezal J, Cohen D, Weissenbach J, Munnich A, Melki J: Identification and characterization of a spinal muscular atrophy-determining gene. Cell 1995, 80:155-165.

7. Monani UR, Coovert DD, Burghes AH: Animal models of spinal muscular atrophy. Hum Mol Genet 2000, 9:2451-2457.

8. Hao LT, Burghes AH, Beattie CE: Generation and characterization of a zebrafish model of SMA carrying the human SMN2 gene. Mol Neurodegener 6:24-32.

9. Takahashi K, Yamanaka S: Induction of pluripotent stem cells from mouse embryonic and adult fibroblast cultures by defined factors. Cell 2006, 126:663-676.

10. Takahashi K, Tanabe K, Ohnuki M, Narita M, Ichisaka T, Tomoda K, Yamanaka S: Induction of pluripotent stem cells from adult human fibroblasts by defined factors. Cell 2007, 131:861-872.

11. Lewitzky M, Yamanaka S: Reprogramming somatic cells towards pluripotency by defined factors. Curr Opin Biotechnol 2007, 18:467-473.

12. Stadtfeld $M$, Hochedlinger $K$ : Induced pluripotency: history, mechanisms, and applications. Genes Dev 2010, 24:2239-2263.

13. Dimos JT, Rodolfa KT, Niakan KK, Weisenthal LM, Mitsumoto H, Chung W, Croft GF, Saphier G, Leibel R, Goland R, Wichterle H, Henderson CE, Eggan K:
Induced pluripotent stem cells generated from patients with ALS can be differentiated into motor neurons. Science 2008, 321:1218-1221.

14. Ebert AD, Yu J, Rose FF, Jr, Mattis VB, Lorson CL, Thomson JA, Svendsen CN: Induced pluripotent stem cells from a spinal muscular atrophy patient. Nature 2009, 457:277-280

15. Marchetto MC, Carromeu C, Acab A, Yu D, Yeo GW, Mu Y, Chen G, Gage FH, Muotri AR: A model for neural development and treatment of Rett syndrome using human induced pluripotent stem cells. Cell 2010, 143:527-539.

16. Soldner F, Hockemeyer D, Beard C, Gao Q, Bell GW, Cook EG, Hargus G, Blak A, Cooper O, Mitalipova M, Isacson O, Jaenisch R: Parkinson's disease patientderived induced pluripotent stem cells free of viral reprogramming factors. Cell 2009, 136:964-977.

17. Swistowski A, Peng J, Liu Q, Mali P, Rao MS, Cheng L, Zeng X: Efficient generation of functional dopaminergic neurons from human induced pluripotent stem cells under defined conditions. Stem Cells 2010, 28:1893-1904

18. Ogawa S, Tokumoto Y, Miyake J, Nagamune T: Immunopanning selection of A2B5-positive cells increased the differentiation efficiency of induced pluripotent stem cells into oligodendrocytes. Neurosci Lett 2011, 489:79-83.

19. Ziegler L, Grigoryan S, Yang IH, Thakor NV, Goldstein RS: Efficient generation of Schwann cells from human embryonic stem cell-derived neurospheres. Stem Cell Rev 2011, 7:394-403.

20. Lee G, Chambers SM, Tomishima MJ, Studer L: Derivation of neural crest cells from human pluripotent stem cells. Nat Protoc 2010, 5:688-701.

21. Liu Y, Zhang SC: Human stem cells as a model of motoneuron development and diseases. Ann N Y Acad Sci 2010, 1198:192-200

22. Malgrange B, Borgs L, Grobarczyk B, Purnelle A, Ernst P, Moonen G, Nguyen L: Using human pluripotent stem cells to untangle neurodegenerative disease mechanisms. Cell Mol Life Sci 2010, 68:635-649.

23. Nizzardo M, Simone C, Falcone M, Locatelli F, Riboldi G, Comi GP, Corti S: Human motor neuron generation from embryonic stem cells and induced pluripotent stem cells. Cell Mol Life Sci 2010, 67:3837-3847.

24. Karumbayaram S, Novitch BG, Patterson M, Umbach JA, Richter L, Lindgren A, Conway AE, Clark AT, Goldman SA, Plath K, Wiedau-Pazos M, Kornblum HI, Lowry WE: Directed differentiation of human-induced pluripotent stem cells generates active motor neurons. Stem Cells 2009, 27:806-811.

25. Lunn MR, Wang CH: Spinal muscular atrophy. Lancet 2008, 371:2120-2133.

26. Axelrod FB, Gold-von Simson G: Hereditary sensory and autonomic neuropathies: types III III, and IV. Orphanet J Rare Dis 2007, 2:39.

27. Slaugenhaupt SA, Blumenfeld A, Gill SP, Leyne M, Mull J, Cuajungco MP, Liebert CB, Chadwick B, Idelson M, Reznik L, Robbins C, Makalowska I, Brownstein M, Krappmann D, Scheidereit C, Maayan C, Axelrod FB, Gusella JF: Tissue-specific expression of a splicing mutation in the IKBKAP gene causes familial dysautonomia. Am J Hum Genet 2001, 68:598-605.

28. Close P, Hawkes N, Cornez I, Creppe C, Lambert CA, Rogister B, Siebenlist U, Merville MP, Slaugenhaupt SA, Bours V, Svejstrup JQ, Chariot A: Transcription impairment and cell migration defects in elongator-depleted cells: implication for familial dysautonomia. Mol Cell 2006, 22:521-531.

29. Lee G, Papapetrou EP, Kim H, Chambers SM, Tomishima MJ, Fasano CA, Ganat YM, Menon J, Shimizu F, Viale A, Tabar V, Sadelain M, Studer L: Modelling pathogenesis and treatment of familial dysautonomia using patientspecific iPSCs. Nature 2009, 461:402-406.

30. Hagberg B: Rett's syndrome: prevalence and impact on progressive severe mental retardation in girls. Acta Paediatr Scand 1985, 74:405-408

31. Amir RE, Van den Veyver IB, Wan M, Tran CQ, Francke U, Zoghbi HY: Rett syndrome is caused by mutations in X-linked MECP2, encoding methylCpG-binding protein 2. Nat Genet 1999, 23:185-188.

32. Chahrour M, Jung SY, Shaw C, Zhou X, Wong ST, Qin J, Zoghbi HY: MeCP2, a key contributor to neurological disease, activates and represses transcription. Science 2008, 320:1224-1229.

33. Muotri AR, Marchetto MC, Coufal NG, Oefner R, Yeo G, Nakashima K, Gage FH: $\mathrm{L} 1$ retrotransposition in neurons is modulated by MeCP2. Nature 2010 468:443-446.

34. Boulting GL, Kiskinis E, Croft GF, Amoroso MW, Oakley DH, Wainger BJ, Williams DJ, Kahler DJ, Yamaki M, Davidow L, Rodolfa CT, Dimos JT, Mikkilineni S, MacDermott AB, Woolf CJ, Henderson CE, Wichterle H, Eggan K: A functionally characterized test set of human induced pluripotent stem cells. Nat Biotechnol 2011, 29:279-286.

35. Schrag A: Epidemiology of movement disorders. In Parkinson's Disease and Movement Disorders. 5th edition. Edited by Tolosa JJaE. Philadelphia: 
Lippincott Williams \& Wilkins; 2007:50-66.

36. Chaudhuri KR, Healy DG, Schapira AH: Non-motor symptoms of Parkinson's disease: diagnosis and management. Lancet Neurol 2006, 5:235-245.

37. Hargus G, Cooper O, Deleidi M, Levy A, Lee K, Marlow E, Yow A, Soldner F, Hockemeyer D, Hallett PJ, Osborn T, Jaenisch R, Isacson O: Differentiated Parkinson patient-derived induced pluripotent stem cells grow in the adult rodent brain and reduce motor asymmetry in Parkinsonian rats. Proc Natl Acad Sci U S A 2010, 107:15921-15926.

38. Nguyen HN, Byers B, Cord B, Shcheglovitov A, Byrne J, Gujar P, Kee K, Schule B, Dolmetsch RE, Langston W, Palmer TD, Pera RR: LRRK2 mutant iPSC-derived DA neurons demonstrate increased susceptibility to oxidative stress. Cell Stem Cell 2011, 8:267-280

39. Ben-Hur T, Idelson M, Khaner H, Pera M, Reinhartz E, Itzik A, Reubinoff BE: Transplantation of human embryonic stem cell-derived neural progenitors improves behavioral deficit in Parkinsonian rats. Stem Cells 2004, 22:1246-1255.

40. Yang D, Zhang ZJ, Oldenburg M, Ayala M, Zhang SC: Human embryonic stem cell-derived dopaminergic neurons reverse functional deficit in parkinsonian rats. Stem Cells 2008, 26:55-63.

41. Sonntag KC, Pruszak J, Yoshizaki T, van Arensbergen J, Sanchez-Pernaute R, Isacson O: Enhanced yield of neuroepithelial precursors and midbrain-like dopaminergic neurons from human embryonic stem cells using the bone morphogenic protein antagonist noggin. Stem Cells 2007, 25:411-418.

42. Seibler P, Graziotto J, Jeong H, Simunovic F, Klein C, Krainc D: Mitochondrial Parkin recruitment is impaired in neurons derived from mutant PINK1 induced pluripotent stem cells. J Neurosci 2011, 31:5970-5976.

43. van Os J, Kapur S: Schizophrenia. Lancet 2009, 374:635-645.

44. Wu EQ, Birnbaum HG, Shi L, Ball DE, Kessler RC, Moulis M, Aggarwal J: The economic burden of schizophrenia in the United States in 2002. J Clin Psychiatry 2005, 66:1122-1129.

45. Sullivan PF, Kendler KS, Neale MC: Schizophrenia as a complex trait: evidence from a meta-analysis of twin studies. Arch Gen Psychiatry 2003, 60:1187-1192.

46. Nestler EJ, Hyman SE: Animal models of neuropsychiatric disorders. Nat Neurosci 2010, 13:1161-1169.

47. Brennand KJ, Simone A, Jou J, Gelboin-Burkhart C, Tran N, Sangar S, Li Y, Mu Y, Chen G, Yu D, McCarthy S, Sebat J, Gage FH: Modelling schizophrenia using human induced pluripotent stem cells. Nature 2011, 473:221-225.

48. Park IH, Arora N, Huo H, Maherali N, Ahfeldt T, Shimamura A, Lensch MW, Cowan C, Hochedlinger K, Daley GQ: Disease-specific induced pluripotent stem cells. Cell 2008, 134:877-886.
49. Kazuki Y, Hiratsuka M, Takiguchi M, Osaki M, Kajitani N, Hoshiya H, Hiramatsu K, Yoshino T, Kazuki K, Ishihara C, Takehara S, Higaki K, Nakagawa M, Takahash K, Yamanaka S, Oshimura M: Complete genetic correction of iPS cells from Duchenne muscular dystrophy. Mol Ther 2010, 18:386-393.

50. Zhang N, An MC, Montoro D, Ellerby LM: Characterization of human Huntington's disease cell model from induced pluripotent stem cells. PLOS Curr 2010, 2:RRN1193.

51. Chamberlain SJ, Chen PF, Ng KY, Bourgois-Rocha F, Lemtiri-Chlieh F, Levine ES, Lalande M: Induced pluripotent stem cell models of the genomic imprinting disorders Angelman and Prader-Willi syndromes. Proc Nat Acad SciU S A 2010, 107:17668-17673.

52. Yang J, Cai J, Zhang Y, Wang X, Li W, Xu J, Li F, Guo X, Deng K, Zhong M, Chen Y, Lai L, Pei D, Esteban MA: Induced pluripotent stem cells can be used to model the genomic imprinting disorder Prader-Willi syndrome. J Biol Chem 2010, 285:40303-40311.

53. Placantonakis DG, Tomishima MJ, Lafaille F, Desbordes SC, Jia F, Socci ND, Viale A, Lee H, Harrison N, Tabar V, Studer L: BAC transgenesis in human embryonic stem cells as a novel tool to define the human neural lineage. Stem Cells 2009, 27:521-532.

54. Hockemeyer D, Soldner F, Beard C, Gao Q, Mitalipova M, DeKelver RC, Katibah GE, Amora R, Boydston EA, Zeitler B, Meng X, Miller JC, Zhang L, Rebar EJ, Gregory PD, Urnov FD, Jaenisch R: Efficient targeting of expressed and silent genes in human ESCs and iPSCs using zinc-finger nucleases. Nat Biotechnol 2009, 27:851-857.

55. Khan IF, Hirata RK, Wang PR, Li Y, Kho J, Nelson A, Huo Y, Zavaljevski M, Ware C, Russell DW: Engineering of human pluripotent stem cells by AAVmediated gene targeting. Mol Ther 2010, 18:1192-1199.

56. Urbach A, Bar-Nur O, Daley GQ, Benvenisty N: Differential modeling of fragile $X$ syndrome by human embryonic stem cells and induced pluripotent stem cells. Cell Stem Cell 2010, 6:407-411.

57. Hotta A, Cheung AY, Farra N, Vijayaragavan K, Seguin CA, Draper JS, Pasceri P, Maksakova IA, Mager DL, Rossant J, Bhatia M, Ellis J: Isolation of human iPS cells using EOS lentiviral vectors to select for pluripotency. Nat Methods 2009, 6:370-376

doi:10.1186/scrt78

Cite this article as: Saporta MA, et al:: Induced pluripotent stem cells in the study of neurological diseases. Stem Cell Research \& Therapy 2011, 2:37. 